Jaana Herranen (Ph.D) is a post-doc researcher in the Unit of Chemistry Teacher Education at the University of Helsinki. Her research interests are inquiry-based science education, student-centred and student-driven education and sustainability education.

Sakari Tolppanen (Ph.D) is a post-doc researcher at the University of Eastern Finland. He has done research on sustainability education and currently focuses mainly on climate change education.

Veli-Matti Vesterinen (Ph.D) is a senior lecturer at the University of Turku. His research interests include educational design research, nature of science and sustainability education. He also plays the ukulele.

Professor Maija Aksela has a 30-year experience in science education and teacher training in Finland. She is the head of the Unit of Chemistry Teacher Education in the Department of Chemistry, University of Helsinki and LUMA Centre Finland. Her research interests are, e.g. sustainability education, teacher education, and non-formal and informal education.

\title{
JAANA HERRANEN
}

Department of Chemistry, Faculty of Science, University of Helsinki

jaana.herranen@helsinki.fi

\section{SAKARI TOLPPANEN}

School of Applied Educational Science and Teacher Education, University of Eastern Finland sakari.tolppanen@gmail.com

\section{VELI-MATTI VESTERINEN}

Department of Chemistry, Faculty of Science and Engineering, University of Turku

vmjves@utu.fi

\section{Challenges and tensions in collaborative planning of a student-led course on sustainability education}

\footnotetext{
Abstract

Student-led courses have been described as a promising approach to improve sustainability education. However, there is a lack of systematic studies about the benefits and challenges of such courses. This qualitative case study examines the challenges and tensions that arose in the planning of a student-led higher education course on sustainability education. The challenges were identified from the student course designers' conversations and interviews using discourse analysis, focusing on their disagreements during planning. The identified challenges concerned sustainability and sustainability education, the course de-
} 
signers' roles, and collaborative decision-making. To relate the challenges to wider discourses on these topics, five underlying tensions were recognized. These include the tension between participatory action and critical discussion approaches for sustainability education, and the tension between drive towards unanimity and agreeing to disagree in collaborative educational planning. Finally, it is discussed how, and to what degree, the challenges and tensions can and should be mitigated.

\section{INTRODUCTION}

The world is facing many challenges, which cannot be solved by doing things the same way as before. These challenges, such as climate change, are often referred to as wicked problems (see Rittel \& Webber, 1973) because they are difficult to solve and require solutions that may be contradicting, incomplete and constantly changing. Furthermore, though wicked problems are urgent and require action, exact consequences of actions are often not known and trying to solve one aspect of a wicked problem may create new, unexpected problems. What is clear is that education plays a central role in trying to solve these problems (e.g. UNESCO, 2016). However, sustainability presents numerous new challenges for education as well (e.g. Blum, Nazir, Breiting, Goh, \& Pedretti, 2013; UNESCO, 2005; Tolppanen \& Aksela, 2018). Thus, also improving sustainability education ${ }^{1}$ can be referred to as a wicked problem with challenges that are hard to define and even harder to solve (see Cantell, Tolppanen, Aarnio-Linnanvuori, \& Lehtonen, 2017; Tolppanen, Aarnio-Linnanvuori, Lehtonen, \& Cantell, 2019). The challenges include inadequate knowledge about sustainability education, lack of resources, support and rewards, as well as lack of climate supporting creativity, innovation, and risk-taking for transformative efforts to reorient education (UNESCO, 2005). Although the challenges seem numerous, it is also clear that the wicked problems of sustainability are so urgent that 'education as usual' will no longer suffice and new approaches are directly needed (UNESCO, 2016).

One of the central challenges of sustainability education has been defining its primary goal (e.g. Blum et al., 2013). Some educators have argued that sustainability education should focus on teaching awareness and understanding, which should lead to change in values and eventually also in behaviour (Sterling, 2010). This view, called the 'ESD 1' (Vare \& Scott, 2007) or the 'instrumental view' (Sterling, 2010), focuses on the urgency of sustainability issues and therefore, tends to provide ready thoughtout ideas and solutions on how individuals and societies should deal with sustainability issues. However, the challenge with this approach is that it tries to show the direction towards a sustainable future even though nobody knows what a sustainable future looks like (Gough \& Scott, 2008). Another view for sustainability education is called the 'ESD 2' (Vare \& Scott, 2007) or 'intrinsic view' (Sterling, 2010). According to this view, sustainability education should focus on developing the students' ability to think critically and make choices in uncertain and complex situations. This view nurtures reflective learning and informed decision-making but may undermine the urgency of sustainability issues (Sterling, 2010; Vare \& Scott, 2007).

To overcome the lack of urgency of ESD 2 and the lack of critical thinking of ESD 1, educators have called for transformative learning (e.g. Sterling, 2010). Transformative learning refers to deeply engaging education, which touches, and changes people's values and beliefs, recognizes the need for change, and emphasizes both relational sensibility and ethical responsibility (Mezirow, 200o; Sterling, 2010). Both the proponents of transformative learning (e.g. Barth, Godemann, Rieckmann, \& Stoltenberg, 2007; McNaughton, 2012; Sterling, 2010), as well as UNESCO (2004) have pointed out, that to really involve people in acting for sustainability, participatory decision-making is required. These participatory processes should emphasize social learning in the community, preferably involving several stakeholders (Disterheft, Azeiteiro, Filho, \& Caeiro, 2015).

The most important group of stakeholders needed for participatory process in sustainability education are the students. Thus, numerous different approaches have been adopted in which students set

\footnotetext{
${ }^{1}$ Researchers sometimes use other terms, such as education for sustainability and/or education for sustainable development (ESD), to emphasise how they define the role of sustainability and development in education.
} 
goals for their learning and are actively involved in what and how they learn. This study focuses on one of them-student-led ${ }^{2}$ sustainability education - which has been mainly utilized in higher education (e.g. Almlöv \& Moberg, 2008; Herranen, Vesterinen, \& Aksela, 2018; Stoddard, 2017). The approach is based on peer teaching, which has been shown to improve students' ability to "acquire new knowledge, practice action skills, shift their environmental behaviour and attitudes, and deepen their ecological values" (de Vreede, Warner, \& Pitter, 2014). In student-led sustainability education, students are responsible for most of the decisions concerning about what and how to learn. On most student-led courses, a group of students is usually provided with the freedom and the accompanying responsibility to design and implement the course for other students. Usually these student course designers do not assume the role of a traditional teacher, but rather facilitate and coordinate collaboration and discussion between the students and other stakeholders such as the faculty and various experts (see Almlöv \& Moberg, 2008; Grandin, 2011; Hällström, 2011). In most previous descriptions of student-led courses, the students' responsibility has been limited in some ways. For example, the students have planned and implemented the course in partnership with researchers and teachers, who provide the students with regular guidance (e.g. Stoddard, 2017) or the students have been responsible for only some parts of the course (e.g. Vesterinen \& Aksela, 2013). There seems to be very few descriptions or studies about entire courses planned and carried out by students with minimal guidance, and without pre-determined goals or approaches to sustainability issues. Studies focusing on such student-led courses could provide insight on how the students involved in planning and carrying out the course about sustainability and its education in practice.

Although there is a need for change on all levels of education, the challenges of sustainability education are especially crucial in teacher education (Firth \& Winter, 2007; UNESCO, 2014). According to UNESCO (2014), teaching and learning environment should be interactive and learner-centred to enable exploratory, action-orientated and transformative learning. Participatory approaches-such as student-led education-in which pre-service teachers take actively part in educational planning, have been seen to have the potential to narrow the theory-practice gap in teacher education (see Struyven, Dochy, \& Janssens, 2010). As the student-led courses are usually planned in groups, involvement in the planning of such courses provides students the opportunity to practice collaborative planning (cf. Soini, Pietarinen, Toom, \& Pyhältö, 2016). Because most of the sustainability issues demand inter- or transdisciplinary approaches (e.g. UNESCO, 2004), planning of student-led sustainability education courses can also provide the students the opportunity to practice collaboration as part of an interdisciplinary team.

However, there are also some recognized challenges, disagreements and concerns over the use of student-led sustainability education (e.g. Grandin, Gunnarsson, \& Andersson, 2017; Pálsdóttir, 2017). One of the central challenges is the scarcity of research on the topic as well as on the tools; materials and frameworks suited for student-led sustainability education (see Læssøe, 2010; Parker, 2010; de Vreede, Warner, \& Pitter, 2014). The collaborative planning and decision-making can also lead to disagreements. For instance, students may have varying views on pedagogy, such as studentcenteredness (see Lea, Stephenson, \& Troy, 2003). However, debating over issues can be seen as an integral part of collaborative learning (e.g. Hamnett, McKie, \& Morrison, 2018). Although some challenges and concerns have been recognized, there seems to be a lack of studies systematically charting the challenges of student-led sustainability education.

\section{RATIONALE AND RESEARCH QUESTIONS}

One of the approaches for increasing student participation in sustainability education is the use of student-led education (e.g. Almlöv \& Moberg, 2008; Herranen et al., 2018; Hällström, 2011). However, as described above, both sustainability education as well as the use of a student-led approach

\footnotetext{
${ }^{2}$ Student-led education is education led by the students instead of the teachers. In this study, the course designers were a group of students. As the course designers had full autonomy to plan the course, they could also choose whether the course was also student-centred, meaning that participants are taken into consideration, being in the centre of learning (Herranen et al., 2018).
} 
present several challenges (e.g. Blum et al., 2013; Grandin et al., 2017). Thus, there is a need for studies describing the use of student-led approaches on various levels of sustainability education, as well as charting the challenges of such approaches and possible causes of those challenges. Although there are some descriptions of experiences in planning and managing student-led courses on sustainability education (e.g. Almlöv \& Moberg, 2008; Grandin, 2011; Heiskanen, Käyhkö, \& Virtanen, 2017), these accounts have not systematically charted the challenges of such courses.

This qualitative case study utilises discourse analysis to identify the challenges that arose when higher education students planned a student-led course on sustainability education. Five student course designers took part in the collaborative planning of the course. The challenges were identified by examining the disagreements that these course designers had during the process of course planning. To understand the challenges more deeply, the course designers were also interviewed about the process and the challenges they faced during planning. Finally, to relate the results of this analysis to a wider discussion on the topic, underlying tensions were recognised comparing the identified challenges to the theoretical frameworks and results from previous studies.

The research questions guiding the analysis were:

1. What are the challenges the course designers face when they plan a student-led course on sustainability education?

2. Which underlying tensions related to student-led sustainability education can explain the challenges the course designers face when they plan the course?

\section{MATERIALS AND METHODS}

\section{Background}

The course Sustainable Development in Education was developed as a pilot course in project ActSHEN - Action for Sustainability in Higher Education in the Nordic region (see Vesterinen, Gollifer, \& Macdonald, 2017). Two previous models inspired the student-led approach used on the course. The first was a collaborative peer teaching model for chemistry teacher education, in which instructors assume a consulting and facilitating role giving the pre-service teachers responsibility and freedom to practice course and lesson planning (see Aksela, 2010; Vesterinen \& Aksela, 2013). The other was the student-led model of instruction developed at the Centre for Environment and Development Studies (CEMUS), in which students develop and run student-initiated courses in dialogue with the faculty (see Grandin, 2011; Hällström, 2011).

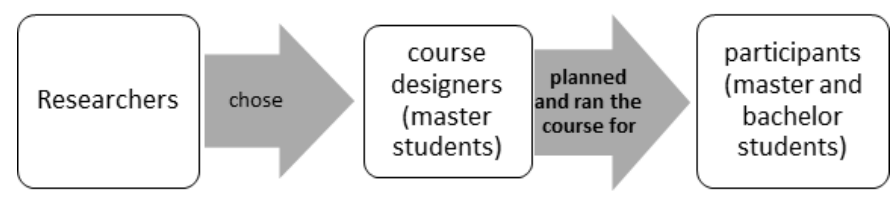

Figure 1. The course design.

Five master students were selected as course designers to plan and run the course (see Figure 1). Although the course designers were majoring in different subjects, all of them had some previous teaching experience and showed a personal interest towards sustainability education (see Appendix 1). However, none of them had prior experience in planning a new course. The master and bachelor students who participated in the course ran by the course designers are referred to as the participants. The course designers received a fixed amount of credits (5 ECTS) for planning and implementing the course. The participants received 3 ECTS credits for the course. 
The course designers were given almost full autonomy over the design and implementation of a course. The authors of this study were teacher educators currently or previously employed by the unit of chemistry teacher education. They selected the course designers, informed them about the restrictions ${ }^{3}$ for the course planning and provided support in administrative tasks, such as reserving classroom spaces and adding the course to students' academic records.

The course designers planned the course for three months. For research purposes, course designers were asked to record all of their conversations, both face-to-face and online, regarding the design of the course. The course designers gave the researchers permission to use this data for research. The course itself included nine six-hour sessions, as well as individual and group work between the sessions. According to the course designers' plans, the first week of the course concentrated on the concept of sustainable development. The second week had more of a pedagogical focus and it concentrated more on sustainability education (see Herranen et al., 2018).

\section{Research method}

The aim of this qualitative case study (see e.g. Denscombe, 2014) was to identify the challenges the course designers had in the design of a course on sustainability education, as well as to recognise the tensions underlying these challenges. The challenges and the tensions were identified and recognised through discourse analysis. Discourse analysis is a descriptive, pragmatic tradition in which the texts are analysed in their contexts to interpret the use of language in social situations, and described as a narrative (e.g. Remes, 2006).

The analysis was carried out in two phases. In the first phase, the challenges in course planning were identified from empirical data utilizing inductive reasoning, because there seems to be no previous research on challenges during the planning of student-led courses on sustainability education. At the beginning of this phase, such discussion sequences in which the course designers seemed to disagree on something related to course design were recognized from the data by the first and second author. Based on the transcriptions of the disagreements during planning as well as on the descriptions of disagreements and challenges the course designers provided during the interview, altogether five overarching challenges were identified.

The empirical data for the study included recordings of the fourteen conversations (1-4 hours each) that the course designers had while planning the course, email communications from the course designers, as well as two semi-structured group interviews of the course designers conducted by the first and second author. The first group interview was carried out after the design phase, and the second after the completion of the course. The interviews focused on the learning process of the course designers, and the challenges the course designers faced during the design and implementation of the course (see Appendix 2). Relevant parts of the interviews and discussions were transcribed verbatim by the first author.

In the second phase, the underlying tensions were recognized by connecting challenges to previous literature on sustainability education and collaborative educational planning using abductive reasoning. Although the use of abductive reasoning has been more widely used and discussed as a part of grounded theory methodology (e.g. Dey, 2004), the approach was used here as part of the discourse analysis to relate the results of the analysis to a wider discourses on the topic (see Remes, 2006).

To ensure that data was not taken out of context, as well as to increase the validity of the analysis, the researchers examined and discussed the selected data together. Validity was increased further by involving the third author in the identification of the challenges and the recognition of the tensions.

\footnotetext{
${ }^{3}$ The only restrictions given to the course designers were that (i) the course needs to be aimed at bachelor and master teacher students; (ii) the course needs to focus on education for sustainability and (iii) the course should run during the two weeks intense study period, a period during which other bachelor and master courses of the semester have already ended.
} 
Interpretations were discussed until the researchers reached consensus. To provide readers with context and to support the interpretations made, direct quotes from the transcriptions are provided when presenting the results. As the discussions were carried out in Finnish, direct quotes were translated from Finnish into English.

As with any other case study, it should be recognized that there are limitations to how far the results can be generalized (see Denscombe, 2014). Although each of the tensions recognized is based on previous studies, it is probable that there are several other possible explanations for these challenges. Thus, to make the reasoning used in recognition of the tensions visible, a brief discussion on the previous research on the issue is provided as part of the description of the tension.

\section{RESULTS}

The challenges and underlying tensions are summarized in table 1 . The results are presented by first describing each challenge and then briefly discussing the tension underlying that specific challenge (see Appendix 3). Even though challenges are presented in a certain order, the design process did not progress in a linear way from defining the concept of sustainability and goals for the course to choosing teaching and learning methods and assigning responsibilities. In fact, in each meeting the course designers usually had disagreements about more than one challenge.

Table 1. Summary of the identified challenges as well as the tensions underlying each identified challenge

\begin{tabular}{|l|l|}
\hline Identified challenge & Recognised tension \\
\hline How to define sustainability? & $\begin{array}{l}\text { Human development vs. Environmen- } \\
\text { tal conservation }\end{array}$ \\
\hline $\begin{array}{l}\text { What should be the focus of sustainability educa- } \\
\text { tion? }\end{array}$ & Affective vs. Cognitive focus \\
\hline How to implement sustainability education? & $\begin{array}{l}\text { Participatory action vs. } \\
\text { Critical discussion approaches }\end{array}$ \\
\hline $\begin{array}{l}\text { What is the role the course designers should as- } \\
\text { sume? }\end{array}$ & Peer role vs. Expert role \\
\hline $\begin{array}{l}\text { How to make decisions during collaborative } \\
\text { educational planning? }\end{array}$ & $\begin{array}{l}\text { Drive towards unanimity vs. Agreeing } \\
\text { to disagree }\end{array}$ \\
\hline
\end{tabular}

\section{Challenge of defining sustainability}

On several occasions, the course designers discussed and debated on how they perceive sustainability and sustainable development. For instance, in the first interview, they talked about how the complexity of the concept is a challenge. Karo was critical to the traditional view of sustainable development, in which sustainable development has three pillars, because it over-emphasises social and economic sustainability. In Karo's opinion, ecological sustainability was the true foundation of a sustainable future.

Not everyone agreed with Karo's claims of over emphasis. During the planning phase, Valo tried to highlight the significance of other dimensions as well:

I agree that out of those, ecology is the most important. However, when talking about sustainable actions, talking about the economy is inevitable... economic sustainability is criticism 
towards companies. Social sustainability is how inequality etc. are taken care of. Ecological responsibility is, as you know, ecological sustainability, but the economy aspect is extremely important, because all actions are done with money and what people do now, they do it with money. But these things do not counter each other, but what is true is that there is a lot of tension between them.

The course designers could not come to an agreement on what the emphasis of sustainable development should be, or more precisely, how strong the focus on environmental aspects should be. Especially when talking about the 'three pillars' of sustainability resulted in debates about how the dimensions should be emphasised. The course designers also had a hard time deciding whether to use the term 'sustainability' or 'sustainable development' but decided to use 'sustainable development' to be in line with the Finnish national frame curricula.

\section{Tension between human development and environmental conservation}

Underlying the challenge of defining sustainability was the tension between human development and environmental conservation. Much like the course designers, researchers have emphasised the dimensions of sustainable development in different ways (e.g. Scott \& Gough, 2003). For example, researchers have debated on how to use the word 'development' and used terms 'weak' and 'strong' sustainability, drawing focus from human development to environmental conservation (Callicott \& Mumford, 1998; Hopwood, Mellor, \& O’Brien, 2005). Proponents of placing the focus on environmental conservation argue that economy is a subset of society and society is completely dependent upon the environment (Scott \& Gough, 2003). They often call their view 'strong sustainability', and the view that focuses more on human development as 'weak sustainability'. However, both approaches have their shortcomings (see Neumayer, 2003). As humans are integrally a part of the social and economic institutions of society, it might be sensible to try to seek viable solutions to sustainability assuming that our fundamental problems are social, economic and political, which then produce environmental symptoms (Scott \& Gough, 2003). Although economic development, human culture and environmental conservation are intertwined and ultimately interdependent, balancing the goals of human development and environmental conservation seems to be one of those wicked problems, where simple solutions just do not exist (Neumayer, 2003; McShane et al., 2011). Thus, there are discussions on whether such a division is relevant at all (Giddings, Hopwood, \& O’Brien, 2002; Hopwood et al., 2005).

\section{Challenge of deciding the focus of sustainability education}

During planning, the course designers had several discussions and disagreements about the goals of sustainability education. Though the course designers themselves did not explicitly identify this as a challenge, the issue was brought up on several occasions. The disagreements rose because some group members wanted to emphasise values, while others wanted to focus more on building the participants knowledge on what sustainability is. For example, Paju saw that values play a key role in sustainability actions, and therefore, argued that they should focus on moulding students' values and choose the pedagogical approaches accordingly:

In my opinion, environmental education is strongly linked to values, and I think they are a strong part of sustainability education as well. We should think about what are the values that we can influence how strongly we can mould someone's values, and what is the best way to do so. When thinking about that, thinking about an appropriate pedagogical approach is also the key.

However, another course designer Valo, argued for the importance of emphasising knowledge. Valo pointed out that one of the challenges was "that the students have a varying level of knowledge on what sustainable development is". Valo argued that focus on sharing knowledge was needed to create a course for students with different backgrounds, and that the course should set a baseline on how sustainability issues should be viewed. 


\section{Tension between cognitive and affective focus}

Underlying the disagreements about the focus of sustainability education was the tension between cognitive versus affective focus in sustainability education. Cognitive focus includes the emphasis of sustainability knowledge, while the affective focus is centred on values, attitudes and behaviour. Although affective focus is considered a central element for education for sustainability (e.g. Leiserowitz, Kates, \& Parris, 2006), openly seeking affective learning outcomes can sometimes be perceived as indoctrination or brainwashing (Shephard, 2008). Even when the importance of an affective focus in learning is acknowledged, some teachers might see affective learning outcomes mainly as 'byproducts' of an increase in knowledge and understanding about sustainability. Thus, balancing between these two foci can be a challenge especially in collaborative planning.

\section{Challenge of deciding how to implement sustainability education}

Making decisions about how to teach sustainability was also identified as a challenge. The course designers had several discussions and disagreements about the pedagogical strategies to be used on the course. For example, Valo expected that they would give lectures and assign clearly framed tasks to students, viewing his role more as a 'traditional' teacher. Other course designers wanted to give the course participants more control over their learning, for example by doing projects. They argued that such projects would provide the course participants skills and materials, which could be later used in practice. They considered it important that the course would meet the needs of the students and encourage action, rather than to provide them with just "a pile of ideas".

For example, Karo saw that sustainability education should focus more on empowering students through more student-centred approaches:

In sustainability education and environmental education, it is important that people get experiences in which they can, through their own actions, affect how the future unfolds...I think that is an essential part of this course and I don't think that in a two-week-long course there is any sense in trying to give the participants more knowledge on the issue. Rather, as the course participants are future teachers, we should focus on giving them tools on how to bring sustainability forward (in schools). They should get a vision of the future and the ability to envision what a sustainable future looks like, not more knowledge, but student-centred approaches that will empower the students.

\section{Tension between participatory action and critical discussion approaches}

Underlying the disagreements about how to implement sustainability education was the tension between participatory action and critical discussion approaches to sustainability education. The urgency of sustainability issues, such as climate change, requires immediate action (see e.g. Sterling, 2010), but focusing on only knowledge does not necessarily lead to action (see Kollmuss \& Agyeman, 2002). Thus, an action-oriented approach is called for (e.g. Chawla \& Cushing, 2011), in which students are seen as not only future citizens or citizens-in-the-making, but also as citizens who actively participate in building a more sustainable world, right here and right now through personal choices and participatory action in their communities (Alderson, 2000; Kahne \& Westheimer, 2006; Vesterinen et al., 2017). However, in the context of sustainability education, a strong emphasis on immediate action might be problematic, especially if it is not backed by research. Without a deep understanding of the nature of a problem, practical projects may focus on providing simplistic or short-sighted 'solutions' to the problem. Due to their oversimplified nature, such solutions may have little-if any-impact in solving complex problems such as sustainability issues (see Skamp, Boyes, \& Stanisstreet, 2013). Thus, students need critical understanding about these problems, to take them into account while working toward a more just and sustainable future (Vare \& Scott, 2007; Sterling, 2010). Concepts such as action competence (e.g. Mogensen \& Schnack, 2010) and resilient learner (Sterling, 2010) have tried to describe a working middle ground between focusing on critical understanding of sustainability issues and building competence for immediate action. 


\section{Challenge of assuming the role of a course designer}

The course designers had different views on how they viewed their own roles during the course and the type of pedagogy they wanted to implement. The disagreements about the role they should assume as course designers slowed down the design process, as they could not go forward with planning before agreeing on it. For example, Karo, Myrsky and Paju did not want to take on the role of an authority or give lectures, and preferred to ask external experts to visit the course as lecturers or panelists:

Myrsky: We have soon given all the lecturing roles to others

Karo: Originally, I didn't even think about us giving lectures. Even if we are organising the course, I don't think we need to be the ones responsible for the teaching.

Paju: I also think that it is better for us to give some of the lecturing roles to outsiders. I'm ready to hold discussions and reflection, but that wouldn't mean that I would be in charge of talking about how different theories or other things go, such as how NGOs are organised.

Myrsky: I didn't think I would be the one lecturing either. I was thinking that it would be someone else, but I was thinking that it would be someone from this group, but I guess we don't have that sort of expertise in this group.

Karo: In general, I don't even think that lecturing is a good way to teach anything in a course. Maybe in some cases yes, but I don't see it as necessary that we have lectures in this course. (Planning meeting)

To this Paju noted that in some cases lecture-type “information-flows” are useful, but didn't see them necessary for this course.

Contrary to the others, Valo had the self-conception of being an expert on certain areas of sustainability and wanted to teach these topics to the participants. Valo had also expected the others to be experts on other dimensions of sustainability rather than on pedagogy. Valo wrote in an email communication:

Mistakenly, I expected the group to consist of members well familiar with sustainability issues; I did not understand the emphasis would be so strongly on pedagogical approaches, such as phenomenon-based learning. My understanding of such pedagogical approaches is around as limited as the other team members' understanding of sustainability issues.

\section{Tension between peer role and expert role}

The challenge was that the course designers did not perceive their role in the same way. They seemed to agree that no one can be an expert in all areas of sustainability education, though some felt more competent to teach on the issue than others. This challenge might be connected to a broader tension between considering one's role as a peer or an expert. On one hand, the course designers viewed themselves as peers for the participants. This provided them with closeness to the participants' perspective and everyday life, which can create a more participatory learning culture than a more traditional teacher-student relationship (see Hald, 2011; Vesterinen et al., 2017). On the other hand, each member of the interdisciplinary team of course designers had expertise on some dimensions of knowledge on sustainability (see Miller, Muñoz-Erickson, \& Redman, 2010) or sustainability education (see de Haan, 2006). Although the course designers familiarised themselves with the topic during planning, it is unlikely that they could reach the professional academics' level of expertise (Parker, 2010). The course designers seemed to be aware of this, and invited experts from various fields as guest lecturers.

\section{Challenge of decision-making during collaborative educational planning}

The course designers discussed in length and had several disagreements about how they should proceed with the planning. Several times the course designers were stuck in fixed positions arguing only for their own viewpoints. For example, when the design process did not advance as smoothly and hastily as some of the course designers had hoped for, they had several disputes on how they should divide the work. The disagreements about decision-making were also discussed during the inter- 
views. Based on these discussions, making decisions during the collaborative educational planning was identified as the fifth challenge. Valo expressed one viewpoint on this issue wanting to distribute work as soon as possible. The other course designers did not want to distribute roles early on in the planning process, preferring to plan each stage of the course together. Valo was frustrated at this and took it personally:

It is good that the group consists of people who want to take responsibility, but if a person who wants responsibility always tries to reject views that are not in line with their own view, it is impossible to share responsibilities.

However, the reason why the other course designers wanted to do the course planning together was that they were interested in co-teaching. For example, Paju replied in the following way:

I do not really see this as a lecture-type course, but rather as a type of conversational course. A course where we do different kinds of student assignments. I would be interested in being there the entire time.

The continuous disagreements between Valo and the rest of the course designers led to the point where Valo decided to leave the group affirming that the group dynamics was indeed a challenge. Valo said the following about the decision:

I believe that me leaving the group will improve the group dynamic. Especially Paju and I have disagreed on many fronts, such as on the content of the course, implementation of group projects, and how to carry out the planning process.

Later on, the others reflected on how they could have improved the planning process, and solved some of the challenges related to it. In retrospect, they agreed that it might have made sense to divide the tasks among the group. They also realised that they should have spent more time in getting to know each other's strengths, as Karo worded it in the second interview:

[From the beginning] we should have put effort into getting to know who everyone is, what our motives are to attend this course, and what kind of strengths we have. These things should have been put to the table right from the start. We [the course designers] should have done some team-building activities... but we never really did.

\section{Tension between drive towards unanimity and agreeing to disagree}

The underlying tension in discussions about the decision-making during collaborative planning was about the level of agreement required to make a decision: whether to focus on finding a unanimous agreement on the issues, or agreeing to disagree and moving forward in sharing responsibilities with some unresolved conflicts. A consensus decision-making approach with a drive towards unanimity focuses on sharing existing knowledge, identifying underlying concerns and constructing new knowledge (Hartnett, 2011). However, sometimes the views, beliefs and values of the decision makers differ so much, that creating one unanimous vision for the project is very challenging (Beers, Boshuizen, Kirschner, \& Gijselaers, 2006). The other approach is to seek a balance between different, contrasting or even opposing viewpoints, without a goal of creating unanimous agreements (see Vesterinen, 2017.). Such 'agreeing to disagree' approach might be especially important in dealing with sustainability issues as solving sustainability challenges require transdisciplinary approaches and epistemological plurality (e.g. Healy, 2003; Miller et al., 2010). The downfall of such an approach is that participants do not necessarily feel ownership of the whole project thus compromising the project's focus. Thus, finding a right balance could be needed to support inclusion, open-mindedness and shared ownership in collaborative decision-making (see Beers et al., 2006; Hartnett, 2011).

\section{DISCUSSION}

\section{Challenges and tensions related to sustainability education}

Three types of challenges and tensions related specifically to sustainability education were found in this study. The first of these challenges was about the definition of sustainability, with an underlying 
tension between the goals of human development and environmental conservation. The following two challenges were about the focus of sustainability education and the methodological approach used in it. The tensions recognised were the conflicts between cognitive and affective focus as well as between participatory action and critical discussion approaches.

Although the tensions related to sustainability education have previously been reduced to two complimentary dimensions, ESD 1 or instrumental and ESD 2 or intrinsic view (e.g. Sterling, 2010; Vare \& Scott, 2007), the results of this study indicated that the three recognized tensions were interconnected, but still separate. For example, the balance between the cognitive and the affective focus is an issue whether one uses an instrumental or an intrinsic approach to sustainability education. Even in the previous categorisations, it has been acknowledged that "there is a spectrum of possible positions and practices across these platforms, and certainly examples of where the two positions are integrated" (Sterling, 2010). Much like the overarching tensions described by Vare and Scott (2007) and Sterling (2010), the tensions recognised here are complementary, with pros and cons on both ends. Therefore, there are no right answers or solutions to the tensions presented. However, based on the results of this study we argue that if the course designers are aware of these tensions and the viewpoints presented in previous research, discussing the potential of various definitions, focuses and approaches to sustainability education can be very rewarding.

\section{Challenges and tensions related to collaborative planning}

In addition to conceptual challenges related to sustainability education, two tensions related to collaborative planning were recognised. The tension concerning their own role as course designers was identified to be between the peer role and expert role, and the tension concerning decision-making was identified to be whether it should be based on unanimity or could the group agree to disagree. Finding a balance between these two tensions can be challenging, especially if course designers are not aware of them.

From the course designers' discussions, it is apparent that the course designers were aware that sustainability education requires a vast amount of expertise. However, they had varying views of what that expertise is and whether they could consider themselves as experts. The majority of the course designers firmly believed that the course should involve a larger community, for instance, by inviting guest speakers to the course. In previous studies, involving a larger community is usually seen as beneficial (e.g. Tolppanen et al., 2017). However, it is noteworthy that the delegation of lecture style teaching to outsiders might also reflect the course designers' feelings of incompetence about assuming the role of an expert. This might also be a concern, which should be taken into account especially in teacher education. Previous research has shown that teachers have only moderate confidence in teaching on sustainability issues (Malandrakis, Papadopoulou, Gavrilakis, \& Mogias, 2019), and lack pedagogical content knowledge on sustainability education (Burmeister \& Eilks, 2013). For primary and secondary school education, constant delegation of expertise to outsiders might not be feasible in the end. Therefore, teacher education should aim to build pre-service teachers' confidence and competence to explore sustainability issues in a way, which does not strongly rely on expertise coming from outside of the school.

Besides different views on their own role, the design process was challenging in the sense that the course designers had disagreements on how they should work as a group and-more specificallywhat drives the decision making process? Both the drive towards unanimity as well as agreeing to disagree are necessary when making the decisions. When aiming at unanimity, the group members have to justify their views and try to come into a joint conclusion on the issue. However, agreeing to disagree is also important as it values multiple ways of knowing and enables making compromise decisions. In fact, such epistemological plurality has been advocated to be used in academic institutions in creating sustainability knowledge (Healy, 2003; Miller et al., 2010). It is especially important in teacher education as inter- or transdisciplinary approaches are needed to tackle the wickedness of sustainability issues (e.g. Burmeister, Rauch, \& Eilks, 2012). Because the course designers' epistemological views were not studied in this research, a claim that the underlying tension would 
have been between epistemological plurality and epistemological sovereignty, can't be made (see e.g. Healy, 2003). However, discussing this tension could have made the decision making process easier, because they could have understood each other's views better and been able to utilise the strengths of the group members more effectively.

\section{Supporting student-led sustainability education}

Students being in a key position in creating their own sustainable future, it is imperative that they participate in educational decision-making (Disterheft et al., 2015). Especially pre-service teachers should be involved with reforming education as they influence the future generations through their profession. The challenges it brings are however visible in this study where the course designers worked together to resolve the challenges. In some cases, the unanimous decision was not reached, but the course designers seemed to agree to disagree. In other cases, the discussion was continued until a unanimous decision was reached, sometimes at the cost of inclusiveness of the decision making (cf. Hartnett, 2011). At least on one occasion, reaching unanimous decision required one of the course designers to leave the group.

One approach to mitigate the challenges and tensions described in this study would be to make the existing challenges and tensions visible to the course designers involved in the planning of the courses. For example, to mitigate the tensions between human development and environmental conservation, the course designers could acquaintance themselves with the discussions on 'strong and weak sustainability' as well as the shortcomings of both approaches (e.g. Neumayer, 2003; Scott \& Gough, 2003). In a similar vein, the challenges related to deciding the goal of and the pedagogical approaches used in sustainability education could be mitigated by familiarizing the course designers with concepts such as action competence and resiliency (e.g. Mogensen \& Schnack, 2010; Sterling, 2010). However, if faculty members decide to provide course coordinators a list of readings, these readings might resemble the preferred theoretical framework of those faculty members rather than the framework the course coordinators or the participants need. The use of outside experts as 'critical friends' might also be a recommendable option to support the course designers in challenges related to sustainability education without unnecessarily undermining their autonomy (see Costa \& Kallick, 1993; Vesterinen, 2017).

The course designers also had difficulties in reaching agreement about their own role. One way to mitigate this challenge would be to set up a mentoring program, which would support the course designers in finding a balance between their dual role as an expert and as a peer (see Grandin, 2011; Hällström, 2011). The course designers involved in this study suggested that they would mentor the next group of course designers. However, there might not always be students with enough experience to act as mentors. On such occasions, collaboration with or even visiting institutions like CEMUS, which has been involved in student-led sustainability education for several years, could support the course designers by giving peer support on planning student-led courses (see Stoddard, 2017).

Out of all the recognized challenges, the tension concerning decision-making might be especially hard to mitigate. People with different scientific backgrounds might have disagreements even about the fundamental epistemological questions, such as what counts as knowing (see Caviglia-Harris \& Hatley, 2004). However, it has been noted that sustainability education requires transdisciplinary approaches and epistemological plurality (see Burmeister et al., 2012; Healy, 2003; Miller et al., 2010). Thus, interdisciplinary groups of students, such as the one involved in this study, might be best suited to tackle the challenges of sustainability education. The course designers involved in this course recommended that the next groups of course designers should have some team-building activities before planning, which might be a viable strategy to mitigate this challenge. Especially working in interdisciplinary teams might require including activities, which enhance communication between team members as well as support inclusion and open-mindedness needed to tackle the challenges related to decision-making in collaborative course planning. 
Although there are several ways to mitigate the challenges identified in this study, one of the crucial questions, which arose from the results of this study, is to what extent this should be done. As can be seen from the results, leaving the challenges unmitigated can certainly lead to personal conflicts and less than optimal inclusiveness of decision-making. However, some of the tensions are not necessarily the kind you can solve, and probably there is not even a need for that. In sustainability education, the students should be encouraged to use time in discussing issues from multiple viewpoints, also exploring the non-popular views (e.g. Sterling, 2010). Facing the challenges provides the course designers countless opportunities for such discussion. Through these discussions, the challenges became part of the learning process mirroring the wickedness of sustainability education. Thus, even though it seems tempting to mitigate the challenges creating conflicts between the course designers, mitigating the conflicts could decrease the autonomy of the course designers, possibly affecting their ownership, motivation and dedication to the course. The fact that the course designers had a fair amount of disagreements during planning is in itself an indication that the students found the issues important on a personal level.

Even if one should carefully consider what type of support is given, it does not mean, that support is not needed. As the experiences from this and other student-led initiatives have shown, the support of the university governance, senior faculty and administrative staff is especially crucial for the continuity of such courses (Almlöv \& Moberg, 2008; Disterheft et al., 2015; Hällström, 2011; Wolff, Sjöblom, Hofman-Bergholm, \& Palmberg, 2017). It is very likely, that in some situations course designers might need significantly more support than the course designers involved in this study received. If such support is needed, it should be provided in ways, which encourage active self-reliance and reflection (see Mogensen \& Schnack, 2010; Sterling, 2010). For example, if we want to provide course designers with support on pedagogical decision-making without diminishing their autonomy, it might be sensible to offer them a wide variety of options and a platform for discussing the decision, rather than offering a fixed pedagogical approach. This would make the decision making an active minds-on process. In addition to providing a variety of tools and viewpoints the support should also leave space for novel and divergent ideas, thus preventing the student participation from becoming a 'self-deceptive simulation', which merely reinforces the dominant discourse and power relations, rather than challenges them (Læssøe, 2010; Grandin et al., 2017).

The aforementioned use of student mentors could be one way to provide the course designers with a critical friend who could support the planning of the course. However, by providing readymade models and ideas based on their experiences of planning and running the course, even mentoring provided by former course designers may result in narrowing the room for truly novel and divergent new ideas. To our knowledge, as there are currently lacking studies on mentoring as a part of student-led sustainability education, there might be need for examining the effect of such mentoring programs on the challenges experienced by the course designers. Because autonomy seems to play such a central part in student-led sustainability education, there might also be a need for a study focusing on how the course designers experience autonomy.

The results of this study indicate that when planning a student-led course on sustainability education, course designers face challenges, which mirror some of the central challenges described in the research on sustainability education. The study also indicates that at least some of the master students are capable of discussing the challenges constructively as well as finding ways to work through them. Thus, student-led approaches seem to be a viable opportunity for improving student participation in sustainability education.

\section{Acknowledgements}

We thank the ActSHEN-partners for contribution during the project, and Nordplus for funding the ActSHEN-project. Research contributions of the third author were also supported by the Finnish Cultural Foundation. 


\section{Declaration of interest}

The authors declare no conflicts of interest.

\section{REFERENCES}

Aksela, M. (2010). Evidence-based teacher education: becoming a lifelong research-oriented chemistry teacher? Chemistry Education Research and Practice, 11(2), 84-91. doi:10.1039/ Coo5350N

Alderson, P. (2000). Citizenship in theory and practice: Being or becoming citizens with rights. In D. Lawton, J. Cairns \& R. Gardner (Eds.), Education for citizenship (pp. 114-135). London: Continuum.

Almlöv, M., \& Moberg, E. (2008). Students in possession of the issues of tomorrow: An innovative student-led course project. Journal of Education for Sustainable Development, 2(2), 173-179. doi:10.1177/097340820800200215

Barth, M., Godemann, J., Rieckmann, M., \& Stoltenberg, U. (2007). Developing key competencies for sustainable development in higher education. International Journal of Sustainability in Higher Education, 8(4), 416-430. doi:10.1108/14676370710823582

Beers, P. J., Boshuizen, H. P. A., Kirschner, P. A., \& Gijselaers, W. H. (2006). Common ground, complex problems and decision making. Group Decision and Negotiation, 15(6), 529-556. doi:10.1007/s10726-006-9030-1.

Blum, N., Nazir, J., Breiting, S., Goh, K. C., \& Pedretti, E. (2013). Balancing the tensions and meeting the conceptual challenges of education for sustainable development and climate change. Environmental Education Research, 19(2), 206-217, doi:10.1080/13504622.2013.780588.

Burmeister, M., \& Eilks, I. (2013). Using participatory action research to develop a course module on education for sustainable development in pre-service chemistry teacher education. Centre for Educational Policy Studies Journal, 3(1), 59-78. Retrieved from https://files.eric.ed.gov/ fulltext/EJ1129463.pdf

Burmeister, M., Rauch, F., \& Eilks, I. (2012). Education for sustainable development (ESD) and chemistry education. Chemistry Education Research and Practice, 13(2), 59-68. doi:10.1039/ C1RP90060A

Callicott, J. B., \& Mumford, K. (1998). Ecological sustainability as a conservation concept. Conservation Biology, 11(1), 32-40. doi:10.1046/j.1523-1739.1997.95468.x

Cantell, H., Tolppanen, S., Aarnio-Linnanvuori, E., \& Lehtonen, A (2019) Bicycle model on climate change education: presenting and evaluating a model. Environmental Education Research, 25(5), 717-731. doi: 10.1080/13504622.2019.1570487

Caviglia-Harris, J., \& Hatley, J. (2004). Interdisciplinary teaching: Analyzing consensus and conflict in environmental studies. International Journal of Sustainability in Higher Education, 5(4), 395-403. doi:10.1108/14676370410561090

Chawla, L., \& Cushing, D. F. (2007). Education for strategic environmental behavior. Environmental Education Research, 13(4), 437-452. doi:10.1080/13504620701581539

Costa, A. L., \& Kallick, B. (1993). Through the lens of a critical friend. Educational Leadership, 51, 49-51. Retrieved from http://www.ascd.org/publications/educational-leadership/oct93/vol51/ num02/Through-the-Lens-of-a-Critical-Friend.aspx

de Haan, G. (2006). The BLK '21' Programme in Germany: A 'Gestaltungskompetenz'-based model for education for sustainable development, Environmental Education Research, 12(1), 19-32. doi:10.1080/13504620500526362

Denscombe, M. (2014). The good research guide: For small-scale social research projects. Maidenhead, Berkshire: Open University Press.

Dey, I. (2004). Grounded theory. In C. Seale, G. Gobo, J.F. Gubrium \& D. Silverman (Eds.), Qualitative research practice (pp. 81-94). London: SAGE Publications Ltd. 
Disterheft, A,. Azeiteiro, U. M., Filho, W. L., \& Caeiro, S. (2015). Participatory processes in sustainable universities - what to assess? International Journal of Sustainability in Higher Education, 16(5), 748-771. doi:10.1108/IJSHE-05-2014-0079

Felder, R. M., \& Brent, R. (2010). Navigating the bumpy road to student-centered instruction. College Teaching, 44(2), 43-47. Retrieved from https://www.jstor.org/stable/27558762

Firth, R., \& Winter, C. (2007). Constructing education for sustainable development: The secondary school geography curriculum and initial teacher training, Environmental Education Research, 13(5), 599-619. doi:10.1080/13504620701659079

Giddings, B., Hopwood, B., \& O’Brien, G. (2002). Environment, economy and society: Fitting them together into sustainable development. Sustainable Development, 1O(4), 187-196. doi:10.1002/ sd.199

Grandin, J., Gunnarsson, S., \& Andersson, S. (2017). "It feels almost surreal”: Being strategic about how we design participation in order to enlarge the space of the possible. LUMAT-B: International Journal on Math, Science and Technology Education, 2(3), 79-83. Retrieved from https://www.lumat.fi/index.php/lumat-b/article/view/272

Grandin, J. (2011). Education for sustainable development is a generational issue - In search of an educational model that will not destroy the planet. In M. Hald (Ed.), Transcending boundaries: How Cemus is changing how we teach, meet and learn (pp. 44-55). Uppsala: CDS Uppsala.

Gough, S., \& W. Scott. (2008). Higher education and sustainable development - Paradox and possibility. London: Routledge.

Hald, M. (2011). A book about CEMUS. In M. Hald (Ed.), Transcending boundaries: How Cemus is changing how we teach, meet and learn (pp. 12-15). Uppsala: CDS Uppsala.

Hamnett, H., McKie, A., \& Morrison, C. (2018). Postgraduate students' attitudes towards group work: experiences within a forensic chemistry programme. Chemistry Education Research and Practice, 4(19), 1240-1252. doi:10.1039/C8RPoo126J

Hartnett, T. (2011). Consensus-oriented decision making. Gabriola Island, BC, Canada: New Society Publishers.

Healy, S. (2003). Epistemological pluralism and the 'politics of choice'. Futures, 35(7), 689-701. doi:10.1016/so016-3287(03)00022-3

Heiskanen, N., Käyhkö, J., \& Virtanen, H. (2017). Students as teachers: A student point of view. LUMAT-B: International Journal on Math, Science and Technology Education, 2(3), 91-93. Retrieved from https://www.lumat.fi/index.php/lumat-b/article/view/275

Herranen, J., Vesterinen, V.-M., \& Aksela, M. (2018). From learner-centered to learner-driven sustainability education. Sustainability, 1O(7), 2190 doi: 10.3390/su10072190

Hopwood, B., Mellor, M., \& O’Brien, G. (2005). Sustainable development: Mapping different approaches. Sustainable Development, 13(1), 38-52. doi:10.1002/sd.244

Hällström, N. (2011). What is education for? The history of Cemus. In M. Hald (Ed.), Transcending boundaries: How Cemus is changing how we teach, meet and learn (pp. 16-33). Uppsala: CDS Uppsala.

Jonassen, D. H. (2000). Revisiting activity theory as a framework for designing student-centered learning environments. In D. H. Jonassen \& S. M. Land (Eds.), Theoretical foundations of learning environments (pp. 89-121). Mahwah, New Jersey: Lawrence Erlbaum Associates.

Kahne, J., \& Westheimer, J. (2006). The limits of political efficacy: Educating citizens for a democratic society. PS: Political Science \& Politics, 39(2), 289-296. doi:10.1017/ s1049096506060471

Kollmuss, A., \& Agyeman, J. (2002). Mind the gap: Why do people act environmentally and what are the barriers to pro-environmental behavior? Environmental Education Research, 8(3), 239-26o. doi:10.1080/13504620220145401

Læssøe, J. (2010). Education for sustainable development, participation and socio-cultural change. Environmental Education Research, 16(1), 39-57. doi:10.1080/13504620903504016 
Lea, S., Stephenson, D., \& Troy, J. (2003). Higher education students' attitudes to studentcentred learning: Beyond 'educational bulimia'? Studies in Higher Education, 28, 321-334. doi:10.1080/03075070309293

Leiserowitz, A. A., Kates, R. W., \& Parris, T. M. (2006). Sustainability values, attitudes, and behaviors: A review of multinational and global trends. Annual Review Environmental Resources, 31, 413-444. doi:10.1146/annurev.energy.31.102505.133552

Malandrakis, G., Papadopoulou, P., Gavrilakis, C., \& Mogias, A. (2019). An education for sustainable development self-efficacy scale for primary pre-service teachers: construction and validation. The Journal of Environmental Education, 5o(1), 23-36. doi:10.1080/00958964.2018.1492366

Mezirow, J. (2000). Learning as transformation: Critical perspectives on a theory in progress. San Francisco: Jossey-Bass.

McNaughton, M. J. (2012). Implementing education for sustainable development in schools: learning from teachers' reflections. Environmental Education Research, 18(6), 765-782. doi:10.1080 /13504622.2012.665850.

McShane, T. O., Hirsch, P. D, Trung, T. C., Songorwa, A. N., Kinzig, A., Monteferri, B., Mutekanga, D. et al. (2011). Hard choices: Making trade-offs between biodiversity conservation and human well-being. Biological Conservation, 144(3), 966-972. doi:10.1016/j.biocon.2010.04.038

Miller, T. R., Muñoz-Erickson, T., \& Redman, C. L. (2010). Transformative knowledge for sustainability: Towards adaptive academic institutions. International Journal of Sustainability in Higher Education, 12(2), 177-192. doi:10.1108/14676371111118228

Mogensen, F., \& Schnack, K. (2010). The action competence approach and the 'new' discourses of education for sustainable development, competence and quality criteria. Environmental Education Research, 16(1), 59-74. doi:10.1080/13504620903504032

Neumayer, E. (2003). Weak versus strong sustainability: Exploring the limits of two opposing paradigms. Northampton: Edward Elgar Publishing.

Pálsdóttir, A. (2017). The emotional challenge of sustainability education. LUMAT-B: International Journal on Math, Science and Technology Education, 2(3), 95-98. Retrieved from https:// www.lumat.fi/index.php/lumat-b/article/view/276

Parker, J. (2010). Competencies for interdisciplinarity in higher education. International Journal of Sustainability in Higher Education, 11(4), 325-338. doi:10.1080/13540600600832296

Remes, L. (2006). Diskurssianalyysin perusteet [The principles of discourse analysis]. In J. Metsämuuronen (Ed.), Laadullisen tutkimuksen käsikirja [Handbook of qualitative research] (pp. 288-374). Jyväskylä: Gummerus.

Rittel, H. W., \& Webber, M. M. (1973). Dilemmas in a general theory of planning. Policy Sciences, 4(2), 155-169. doi:10.5040/9781474282932.0015

Scott, W., \& Gough, S. (2003). Sustainable development and learning: Framing the issues. London: Routledge.

Shephard, K. (2008). Higher education for sustainability: Seeking affective learning outcomes. International Journal of Sustainability in Higher Education, 9(1), 87-98. doi:10.1108/14676370810842201

Skamp, K., Boyes, E., \& Stanisstreet, M. (2013). Beliefs and willingness to act about global warming: Where to focus science pedagogy? Science Education, 97(2), 191-217. doi:10.1002/sce.21050

Soini, T., Pietarinen, J., Toom, A., \& Pyhältö, K. (2016). Haluanko, osaanko ja pystynkö oppimaan taitavasti yhdessä muiden kanssa? [Do I have the willingness, skill and capability to learn skilfully with others?] In H. Cantell \& A. Kallioniemi (Eds.), Kansankynttilä keinulaudalla: Miten tulevaisuudessa opitaan ja opetetaan [Teacher in a seesaw: How we learn and teach in the future?] (pp. 53-76). Jyväskylä: PS-kustannus.

Sterling, S. (2010). Learning for resilience, or the resilient learner? Towards a necessary reconciliation in a paradigm of sustainable education. Environmental Education Research, 16(5-6), 511-528. doi:10.1080/13504622.2010.505427 
Stoddard, I. (2017). Copy but don't paste: From student-led to collaborative action for sustainability in higher education. LUMAT-B: International Journal on Math, Science and Technology Education, 2(3), 27-32. Retrieved from https://www.lumat.fi/index.php/lumat-b/article/view/262

Struyven, K., Dochy, F., \& Janssens, S. (2010). Teach as you preach': The Effects of student-centred versus lecture-based teaching on student teachers' approaches to teaching. European Journal of Teacher Education, 33(1), 43-64. doi:10.1080/02619760903457818

Tolppanen, S., \& Aksela, M. (2018). Identifying and addressing students' questions on climate change”. Journal of Environmental education, 49(5), 375-389. doi:10.1080/00958964.2017.1417816

Tolppanen, S., Aarnio-Linnanvuori, E., Lehtonen, A. and Cantell, H. (2017). Pirullisen ongelman äärellä: Kokonaisvaltainen ilmastokasvatuksen malli [Dealing with a wicked problem: A model for holistic climate change education]. Kasvatus, 48(5), 456-468.

Toom, A., Husu, J., \& Tirri, K. (2015). Cultivating student teachers' moral competencies in teaching during teacher education. In C. C. Craig \& L. Orland-Barak (Eds.), International teacher education: Promising pedagogies. (Part C, pp. 13-31). UK: Emerald Publishing.

UNESCO (2004). United nations decade of education for sustainable development: Draft international implementation scheme 2005-2014. Paris: UNESCO.

UNESCO (2005). Guidelines and recommendations for reorienting teacher education to address sustainability. Paris: UNESCO.

UNESCO (2014). Roadmap for implementing the global action programme on education for sustainable development. Paris: UNESCO.

UNESCO, Global education monitoring report 2016. Education for people and planet: Creating sustainable futures for all. Paris: UNESCO.

Vare, P., \& Scott, W. (2007). Learning for a change: Exploring the relationship between education and sustainable development. Journal of Education for Sustainable Development, 1(2), 191198. doi:10.1177/097340820700100209

Vesterinen, V.-M. (2017). Helsinki framework: Co-design of principles for sustainability education. LUMAT-B: International Journal on Math, Science and Technology Education, 2(3), 15-18. Retrieved from https://www.lumat.fi/index.php/lumat-b/article/view/26o

Vesterinen, V.-M., Gollifer, S., \& Macdonald, A. (2017). ActSHEN: Action for sustainability in higher education. LUMAT-B: International Journal on Math, Science and Technology Education, 2(3), 3-11. Retrieved from https://www.lumat.fi/index.php/lumat-b/article/view/300

Vesterinen, V.-M., \& Aksela, M. (2013). Design of chemistry teacher education course on nature of science. Science \& Education, 22(9), 2193-2225. doi:10.1007/s11191-012-9506-0

de Vreede, C., Warner, A., \& Pitter, R. (2014). Facilitating youth to take sustainability actions: The potential of peer education. The Journal of Environmental Education, 45(1), 37-56. doi:10.108 o/00958964.2013.805710

Wolff, L.-A., Sjöblom, P., Hofman-Bergholm, M., \& Palmberg, I. (2017). High performance education fails in sustainability? -A reflection on Finnish primary teacher education. Education Sciences, 7(1), 32. doi:10.3390/educsci7010032 


\section{APPENDICES}

\section{Appendix 1}

The backgrounds of selected course designers

\begin{tabular}{|l|l|}
\hline Name & Background \\
\hline Paju & $\begin{array}{l}\text { Master student in chemistry education with interest towards sustainability edu- } \\
\text { cation. Worked as a substitute teacher alongside studies. }\end{array}$ \\
\hline Karo & Master student in environmental sciences, with minor studies in adult education. \\
\hline Myrsky & $\begin{array}{l}\text { Master student in mathematics education with interest towards sustainability } \\
\text { education. Worked part-time as a teaching assistant at the department of math- } \\
\text { ematics. }\end{array}$ \\
\hline Valo & $\begin{array}{l}\text { Master student in theology with coaching experience on developing environmen- } \\
\text { tal responsibility in private companies. Took part in the design of the course, but } \\
\text { did not participate in running the course. }\end{array}$ \\
\hline Nikola & $\begin{array}{l}\text { Master student in environmental sciences with teaching experience from a } \\
\text { student-led project course on sustainability. Took part in the design of the course } \\
\text { as an advisor, but did not participate in running the course. }\end{array}$ \\
\hline
\end{tabular}

\section{Appendix 2}

\section{The structure for the first interview}

- How did you decide to emphasize the different dimensions of sustainability and why?

- How do you think your students will react to what you teach?

- What was the significance of the CEMUS-visit?

- How are you going to support the group work of the participants?

- How do you feel about the course?

- How have you experienced the planning process?

- How important do you think is the pedagogical background for the course designers?

- How have you experienced the group work?

- What have you learned in the process?

\section{The structure for the second interview}

- What do you think you learned in the course?

- Where did you learn about those things?

- Did you change your plans during the course?

- What kind of experience was this in terms of your future as teacher?

- How would you choose the next course designers?

- How would you develop the course?

- Would you do something differently now after the course?

- What kind of feelings you experienced in planning the course?

- How was student-centredness actualized in the course?

- How has your thinking about sustainability and its education changed in the process? What was challenging in planning the course?

- How do you think multi-, inter-, or transdisciplinary was actualized in the course?

- How do you think that the different backgrounds of the course designers affected to the course? 
Herranen et al.

\section{Appendix 3}

Example of the analysis

\begin{tabular}{|c|c|c|}
\hline $\begin{array}{l}\text { Empirical observation } \\
=\text { challenge }\end{array}$ & Theory = tension & $\begin{array}{l}\text { Possible explanation for } \\
\text { the empirical observation } \\
=\text { result of the study }\end{array}$ \\
\hline
\end{tabular}

The course designers When defining sustainability,

The course designers' discus-

had disagreements about there can be seen a tension sions about sustainability different sustainability between emphasizing human definitions are linked to the definitions development and environmental conservation tension between emphasizing human development and environmental conservation 